\title{
Analysis of vitexin in aqueous extracts and commercial products of Andean Passiflora species by UHPLC-DAD
}

\author{
Paula Sepúlveda ${ }^{1}$, Geison M. Costa ${ }^{2 *}$, Diana Marcela Aragón ${ }^{1}$, Freddy Ramos ${ }^{3}$, Leonardo Castellanos ${ }^{3}$ \\ ${ }^{1}$ Universidad Nacional de Colombia - Bogotá D.C. - Facultad de Ciencias - Departamento de Farmacia - Cra. 30 N 45-03, Bogotá 111321, Colombia. \\ ${ }^{2}$ Pontificia Universidad Javeriana, Bogotá D.C. - Facultad de Ciencias - Departamento de Química - Cra 7, N 43-83, Colombia. \\ ${ }^{3}$ Universidad Nacional de Colombia - Bogotá D.C. - Facultad de Ciencias - Departamento de Química - Cra. 30 N 45-03, Bogotá 111321, Colombia
}

\section{ARTICLE INFO \\ Article history: \\ Received on: $27 / 11 / 2017$ \\ Accepted on: 29/04/2018 \\ Available online: 30/09/2018 \\ Key words: \\ Passiflora, vitexin, flavonoids, UHPLC, quality control.}

\begin{tabular}{|c|}
\hline ABSTRACT \\
\hline $\begin{array}{l}\text { Plants of the Passiflora genus are extensively cultivated in South America, as their edible fruits are widely } \\
\text { commercialized. They are also recognized worldwide for their ethnopharmacological uses. Different Pharmacopoeias } \\
\text { indicate vitexin as the chemical marker for } P \text {. incarnata, the most widely studied Passiflora species worldwide. In } \\
\text { the present work, some species of Passiflora from the Andean region of Colombia and commercial phytotherapeutic } \\
\text { products were evaluated for their vitexin content by UHPLC-DAD. From the studied species: 'banana passion fruits' } \\
\text { (P. tripartita var tripartita, } P \text {. tripartita var mollissima, } P \text {. mixta, } P \text {. cumbalensis, } P \text {. tarminiana), 'passion fruits' }(P \text {. } \\
\text { edulis var flavicarpa, } P \text {. edulis var edulis), 'granadillas', (P. ligularis, } P \text {. quadrangularis) and 'sweet passion fruit' } \\
\text { (P. alata), the aqueous extracts of } P \text {. mixta, } P \text {. tripartita var mollissima and } P \text {. edulis var } \text { edulis showed quantifiable } \\
\text { amounts of vitexin }\left(4.58 \pm 1.23 ; 2.49 \pm 0.2 ; 0.3 \pm 0.0 \mathrm{mg} \mathrm{g}^{-1} \text { dry extract, respectively). Additionally, four of the six }\right. \\
\text { botanical phytotherapeutic products tested showed considerable quantities of this flavonoid. The results obtained } \\
\text { suggest that vitexin cannot be used as the only chemical marker for the quality control of the studied } \text { Passiflora species. }\end{array}$ \\
\hline
\end{tabular}

\section{INTRODUCTION}

More than 500 species comprise the Passiflora genus, growing in the form of lianas or vines that climb by tendrils, or as arboreous or shrub-like species (Hernández and Bernal, 2000). Latin America has the highest occurrence of these species, commonly known as passion fruits; Colombia, Brazil, Ecuador, and Perú are the countries with the highest diversity of the species (Fischer and Rezende, 2008).

These plants have important economic, ornamental and biological uses. Some ethnopharmacological uses and reported activities include diuretic, analgesic, anxiolytic, anti-inflammatory, hypoglycemic, antioxidant, antispasmodic, and neuroprotective activities, among others (Dhawan et al., 2004; Patel et al., 2011).

In previous chemical studies on this genus, different classes of secondary metabolites have been identified (alkaloids,

\footnotetext{
"Corresponding Author

Geison M. Costa, Departamento de Química, Facultad de Ciencias, Pontificia Universidad Javeriana, Bogotá D.C., Colombia; Pontificia Universidad Javeriana, Building 52, Office 617 - Cra 7, $N^{\circ}$ 43-83, Colombia.E-mail: modesticosta.g@javeriana.edu.co
}

cyanogenic glycosides, fatty acids, terpenes and saponins), with flavonoids being reported as having most of the pharmacological properties described for these species (Dhawan et al., 2004; Patel et al., 2011; Farag et al., 2016). Vitexin is one of the most frequently reported flavonoids for Passiflora (Costa et al., 2013).

Based on several studies that show preclinical and clinical evidence of pharmacological activity of Passiflora, some species are included in official pharmacopeias. There are monographs of $P$. incarnata $\mathrm{L}$ in the European, British and Spanish Pharmacopoeias (European Pharmacopoeia, 2011; British Pharmacopoeia, 2009; Real Farmacopea Española, 2002) while P. edulis and P. alata are included in the Brazilian Pharmacopoeia (Agência Nacional de Vigilância Sanitária, 2010). In all these monographs, one of the tests described to confirm the identity of the species is by Thin Layer Chromatography, which evaluates the flavonoids fingerprint, including the presence of vitexin. In quantitative terms, the assay seeks to determine the total flavonoids, expressed as vitexin in Passiflora incarnata or as apigenin in P. alata and P. edulis, by colorimetric method. Only the Brazilian Pharmacopoeia describes another identification test, which is based on the HPLC profile. 
In this context, the aim of this work was to determine the vitexin content of some Colombian Andean Passiflora species and commercial products by Ultra-High Performance Liquid Chromatography (UHPLC), in order to evaluate the usefulness of this flavonoid as a chemical marker of the analyzed species.

\section{METHODOLOGY}

\section{General methods}

For the extraction procedures, distilled water was used. Acetonitrile-HPLC grade (Merck), formic acid RA (Merck), and water purified using a Milli-Q system (Millipore $\left.{ }^{\circledR}\right)$ were filtered through a $0.22 \mu \mathrm{m}$ membrane (CNW Technologies) and degassed by ultrasound bath before UHPLC analysis. The reference standard used was vitexin (Fluka, 95\%).

The UHPLC analyses were carried out in a Thermo scientific Dionex Ultimate 3000 equipped with Dionex Ultimate
3000 Diode Array Detection (DAD), Dionex Ultimate 3000 RS Pump, on-line degasser and autosampler. The data were processed using the software Chromeleon Client, version 6.80 SR15.

\section{Plant material and extraction}

Aerial parts of Passiflora species were collected from different places of the Colombian Andean region (Table 1). The leaves were air dried separately at $40^{\circ} \mathrm{C}$ and finely powdered. $10 \mathrm{~g}$ of leaves from each species were extracted, separately, by infusion with $100 \mathrm{~mL}$ of boiling water $\left(95^{\circ} \mathrm{C}\right.$, plant:solvent $1: 10$, $\mathrm{w} / \mathrm{v}$ ) for 10 minutes, then filtered, centrifuged at $5000 \mathrm{rpm} / 30$ min and finally, the supernatant was frozen and lyophilized to obtain the crude extract. The samples for UHPLC analysis were prepared by dissolving $1.0 \mathrm{mg}$ of the dried crude extracts in 1 $\mathrm{mL}$ of methanol:water $(1: 1, \mathrm{v} / \mathrm{v})$ and filtering through a $0.22 \mu \mathrm{m}$ membrane before injection.

Table 1: Passiflora species with their respective collection zones and quantification of vitexin in crude extracts.

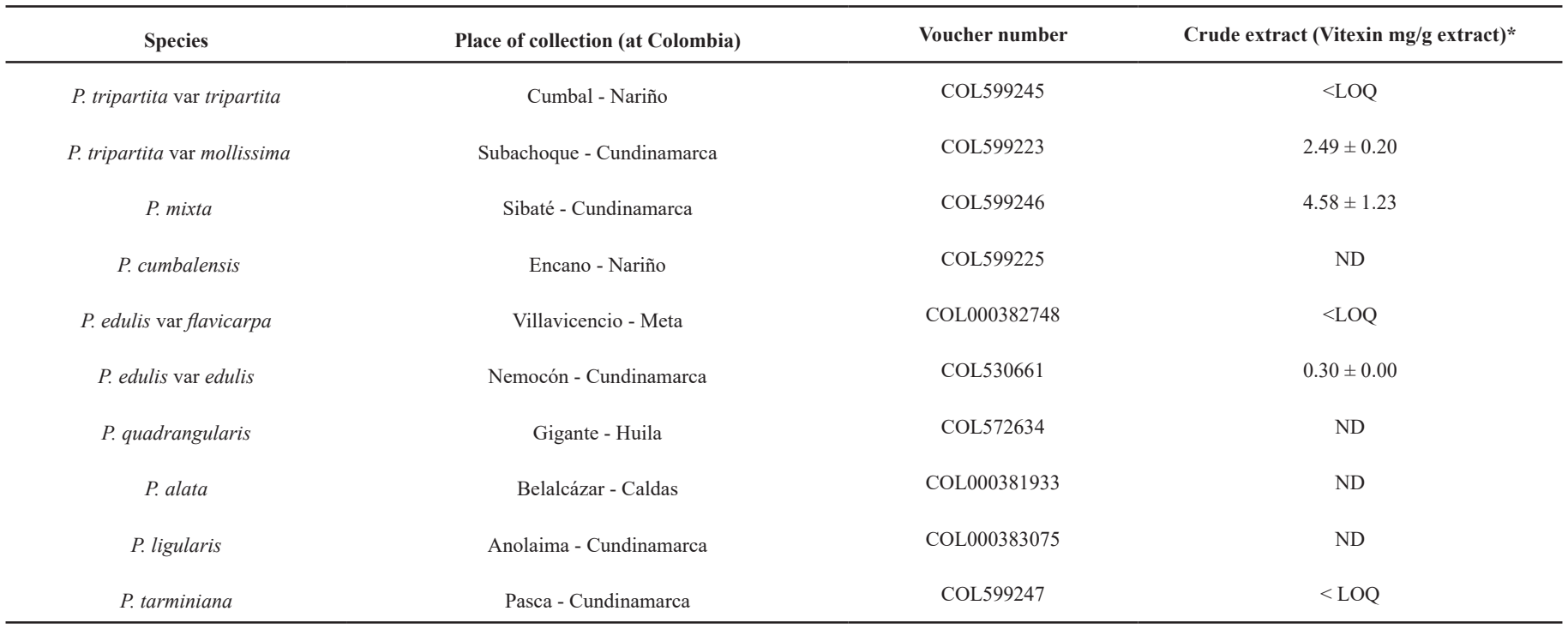

$* \mathrm{ND}=$ Not detected. The data represent the mean $\pm \mathrm{SD}$ of three replicates.

\section{Passiflora botanical drugs}

For this study, we selected some Passiflora botanical drugs from health food stores in Bogotá, Colombia (Table 2). Were included in the study only products containing exclusively Passiflora leaf extracts in its composition, excluding products that contained flower extracts, products containing mixtures of distinct plant extracts and homeopathic products.

For products in drops, $500 \mu \mathrm{L}$ of the product was diluted with $500 \mu \mathrm{L}$ of a methanol-water solution $(1: 1)$. In the case of capsules, $15 \mathrm{mg}$ of the dry powdered content was dissolved in 1 $\mathrm{mL}$ of methanol-water $(1: 1)$. All samples were filtered through a $0.22 \mu \mathrm{m}$ membrane before injection.

\section{Chromatographic conditions}

The UHPLC analysis was performed in a UHPLC Dionex ultimate 3000 as previously described. A Phenomenex ${ }^{\circledR}$ Kinetex C18 column $(100 \times 2.1 \mathrm{~mm} ; 2.6 \mu \mathrm{m})$ was used at a temperature of $35^{\circ} \mathrm{C}$, the flow rate was kept constant at $0.3 \mathrm{ml} /$ min, and the injection volume was $3 \mu \mathrm{L}$ Detection was performed at a wavelength of $340 \mathrm{~nm}$, with DAD spectra acquired between 200 and $450 \mathrm{~nm}$. The gradient system combined $0.5 \%$ formic acid (solvent A) and acetonitrile (solvent B). It started with 10-35\% B (0-8 min), followed by $35 \% \mathrm{~B}$ (8-9 min), 35-85\% B (9-15 min) and $85-10 \% \mathrm{~B}$ (15-16 $\mathrm{min})$. The re-equilibration time was $8 \mathrm{~min}$ between individual analyses.

\section{Standard solutions and calibration}

From a vitexin stock solution $(240 \mu \mathrm{g} / \mathrm{mL})$ prepared in methanol-water $(1: 1, \mathrm{v} / \mathrm{v})$, different standard solutions were prepared as follows: $1.5,6.0,12.0,24.0,48.0,96.0$, and $144.0 \mu \mathrm{g} / \mathrm{mL}$. All standard solutions were filtered through a $0.22 \mu \mathrm{m}$ membrane, analyzed in triplicate, and the peak average areas measured.

\section{Validation of analytical procedures}

The validation of analytical procedures was performed according to the ICH guidelines (ICH, 2005). The validated 
parameters were specificity, linearity, accuracy, precision (repeatability and intermediate precision), limit of detection (LOD) and limit of quantification (LOQ).

Table 2: Passiflora phytotherapeutic description and vitexin quantification.

\begin{tabular}{ccccc}
\hline Product & $\begin{array}{c}\text { Dosage } \\
\text { form }\end{array}$ & Claimed species & Type of extract & $\begin{array}{c}\text { Vitexin } \\
(\boldsymbol{\mu g} / \mathbf{m L} \text { extract) }\end{array}$ \\
\hline A-1 & Drops & P. mollissima* & Hydroalcoholic & $24.20 \pm 1.00$ \\
A-2 & Capsules & P. mollissima* & Ethanolic & $3.03 \pm 0.18$ \\
B-1 & Drops & P. mollissima* & Unspecified & $39.50 \pm 1.94$ \\
B-2 & Drops & P. mollissima* & Unspecified & $55.60 \pm 3.04$ \\
C-1 & Drops & P. incarnata & Unspecified & ND \\
C-2 & Drops & P. incarnata & Unspecified & ND \\
\hline
\end{tabular}

*It refers to Passiflora tripartita var mollissima (Cardozo et al., 2009). ND: Not Detected. Data represent the mean $\pm \mathrm{SD}$ of three replicates.

\section{RESULTS AND DISCUSSION}

As described earlier, flavonoids are the most frequently metabolites reported in species of the Passiflora genus. Among the species analyzed in this study, Passiflora ligularis, P. tarminiana, P. mixta, $P$. cumbalensis, P. tripartita var mollissima, $P$. tripartita var tripartita, and $P$. edulis var flavicarpa showed the most complex flavonoid profiles, with several peaks corresponding to these metabolites (identified by their DAD spectra - data not shown). All of them belong to the Taxonia subgenus, also known as banana passion fruits. With the exception of $P$. edulis var flavicarpa, which belongs to Passiflora subgenus (Ocampo et al., 2007). The complexity of the extract composition was one of the challenges to be overcome when developing the analytical method for the analysis of different Passiflora species. Although the developed methodology does not allow the separation of all flavonoids peaks from the samples, especially the complex ones, it enabled the differentiation of flavonoids fingerprint from each the extracts.

\section{Method validation}

\section{Linearity and sensitivity}

From the regression coefficient $\left(\mathrm{r}^{2}\right)$ obtained, the method developed for the quantification of vitexin showed good correlation between the response and the concentration of the flavonoid. In addition to least-squares regression, ANOVA analysis was also performed to confirm the significant regression of the method. The calculated F value was 17809.414 , which is higher than the tabulated $\mathrm{F}$ value $\left(\mathrm{F}_{1,19}=4,381\right)$ at a $95 \%$ confidence level, demonstrating that the regression was significant. The limits of detection (LOD) and quantitation (LOQ) were determined by successive dilutions of the calibration curve until a signal to noise ratio of 10:1 was observed, with a relative standard deviation (\% RSD) $>5 \%$ for the LOQ and a ratio of 3:1 for the LOD (Table 3).

Table 3: Calibration, sensitivity and precision data for vitexin standard solutions.

\begin{tabular}{|c|c|c|c|c|c|c|c|c|c|}
\hline Flavonoid & $\begin{array}{l}\text { Linearity } \\
\text { range } \\
(\mu \mathrm{g} / \mathrm{mL})\end{array}$ & Calibration equation $^{\mathrm{a}}$ & $\begin{array}{c}\text { Regression } \\
\text { coefficient } \\
\left(\mathbf{r}^{2}\right)\end{array}$ & $\begin{array}{c}\text { Calculated } \\
\text { F }^{\mathrm{b}}\end{array}$ & $\begin{array}{c}\text { LOD } \\
(\mu \mathrm{g} / \mathrm{mL})^{\mathrm{c}}\end{array}$ & $\begin{array}{c}\text { LOQ } \\
(\mu \mathrm{g} / \mathrm{mL})^{\mathrm{d}}\end{array}$ & $\begin{array}{c}\text { Concentration } \\
(\mu \mathrm{g} / \mathrm{mL})\end{array}$ & $\begin{array}{c}\text { Repeatability }^{\mathrm{e}}(1 \\
\text { day, } \mathrm{n}=3 \% \text { RSD) }\end{array}$ & $\begin{array}{c}\text { Intermediate } \\
\text { precision }^{\mathrm{e}} \text { (3 days, } \\
\text { n=3 \% RSD) }\end{array}$ \\
\hline \multirow{3}{*}{ Vitexin } & \multirow{3}{*}{$1.5-144$} & \multirow{3}{*}{$y=0.266 x+0.0748$} & \multirow{3}{*}{0.9991} & \multirow{3}{*}{17809.414} & \multirow{3}{*}{0.40} & \multirow{3}{*}{0.60} & 12.0 & 1.15 & 0.51 \\
\hline & & & & & & & 48.0 & 1.06 & 0.88 \\
\hline & & & & & & & 144.0 & 1.39 & 0.74 \\
\hline
\end{tabular}

${ }^{\text {a }}$ Six data points $(\mathrm{n}=3) .{ }^{\mathrm{b}}$ Tabulated $\mathrm{F}$ value $\left(\mathrm{F}_{1,19}=4,381\right)$ at a $95 \%$ confidence level. ${ }^{\mathrm{c}} \mathrm{LOD}$ : limit of detection. ${ }^{\mathrm{d}} \mathrm{LOQ}$ : limit of quantitation. ${ }^{\mathrm{e}} \mathrm{RSD}<5 \%$

\section{Precision and accuracy}

Precision was evaluated as repeatability and intermediate precision. Three concentration levels of the standard solutions were analyzed in triplicate within one day and on three consecutive days, respectively. Both parameters were satisfactory (Table 3 ) since the relative standard deviation (RSD) to all values were found to be below $5 \%$, according to the limit recommended in the ICH guideline.

Accuracy was expressed as the recovery percentage obtained after spiking a sample with known amounts of the standard solution (Table 4); it was calculated using the equation: Recovery $(\%)=($ Theoretical content $\times 100) /$ Experimental content . The reported data represents the average percentage of triplicates and its relative standard deviation.

\section{Vitexin quantification in Passiflora extracts}

In general, Passiflora crops require constant pruning throughout the harvest and postharvest seasons to improve the structure of the plants and increase their productivity (Ocampo and Wyckhuys, 2012). This good agricultural practice generates a large number of leaves that are considered as waste, but due to its previously reported pharmacological activity, it could be used to produce botanical drugs. However, one of the first steps necessary to develop a safe, effective, high-quality botanical drugs is to implement analytical techniques to quantify the chemical or therapeutic markers of both the raw material and the final product.

Ten samples of cultivated Passiflora species were analyzed for their vitexin content. Some of them have been previously studied by our group, and the presence of major metabolites such as vitexin-2"-O-xyloside in P. quadrangularis and vitexin-2"-O-rhamnoside in P. alata has been observed in the leaf extracts. Some $C$-glycosyl flavonoids have been identified in $P$. tripartita var mollissima like vicenin-2, isoorientin, orientin, isovitexin, vitexin (Zucolotto et al., 2012) and the orientin derivative 4'-methoxyluteolin-8-C-6"'acetylglucopyranoside (Ramos et al., 2010). Significant differences have been identified 
in the two varieties of Passiflora edulis; the major flavonoids in the aerial parts of $P$. edulis var flavicarpa, such as lucenin-2, vicenin-2, isoorientin, isovitexin, luteolin-6- $C$-chinovoside, and luteolin-6-C-fucoside, were not observed in $P$. edulis var edulis (Li et al., 2011; Zucolotto et al., 2012), which contains vitexin2"-O-rhamnoside and luteolin-7-O-glucoside in its flavonoid composition (Ayres et al., 2015).

Table 4: Accuracy data.

\begin{tabular}{cccc}
\hline \multirow{2}{*}{ Species } & Flavonoid & \multicolumn{2}{c}{ Recovery } \\
\cline { 3 - 4 } & & Mean (\%) & RSD (\%) \\
\hline $\begin{array}{c}\text { P. tripartita } \text { var mollissima } \\
(500 \mathrm{uL} / \mathrm{mL})\end{array}$ & Vitexin $(48 \mu \mathrm{g} / \mathrm{mL})$ & 99.0 & 2.94 \\
\hline
\end{tabular}

To the best of our knowledge, no UHPLC profiles are reported in the literature for $P$. cumbalensis, $P$. tarminiana, $P$. tripartita var tripartita, P. ligularis and P. mixta.

In this study, vitexin was detected in $P$. edulis var edulis, P. tripartita var mollissima, P. mixta, $P$. edulis var flavicarpa, $P$. tarminiana and $P$. tripartita var. tripartita leaf extracts. Although only $P$. edulis var edulis, $P$. tripartita var mollissima, $P$. mixta contained vitexin above the quantifiable limits of the method; $0.3 \pm 0.0 \mathrm{mg} \mathrm{g}^{-1}$ of extract for $P$. edulis var edulis; $2.49 \pm 0.2$ $\mathrm{mg} \mathrm{g}^{-1}$ of extract for P. tripartita var mollissima; and $4.58 \pm 1.23$ $\mathrm{mg} \mathrm{g}^{-1}$ of extract for P. mixta, the highest amount (Table 1 and Figure 1). However, no vitexin was detected in $P$. cumbalensis, $P$. ligularis, $P$. quadrangularis, and P. alata.

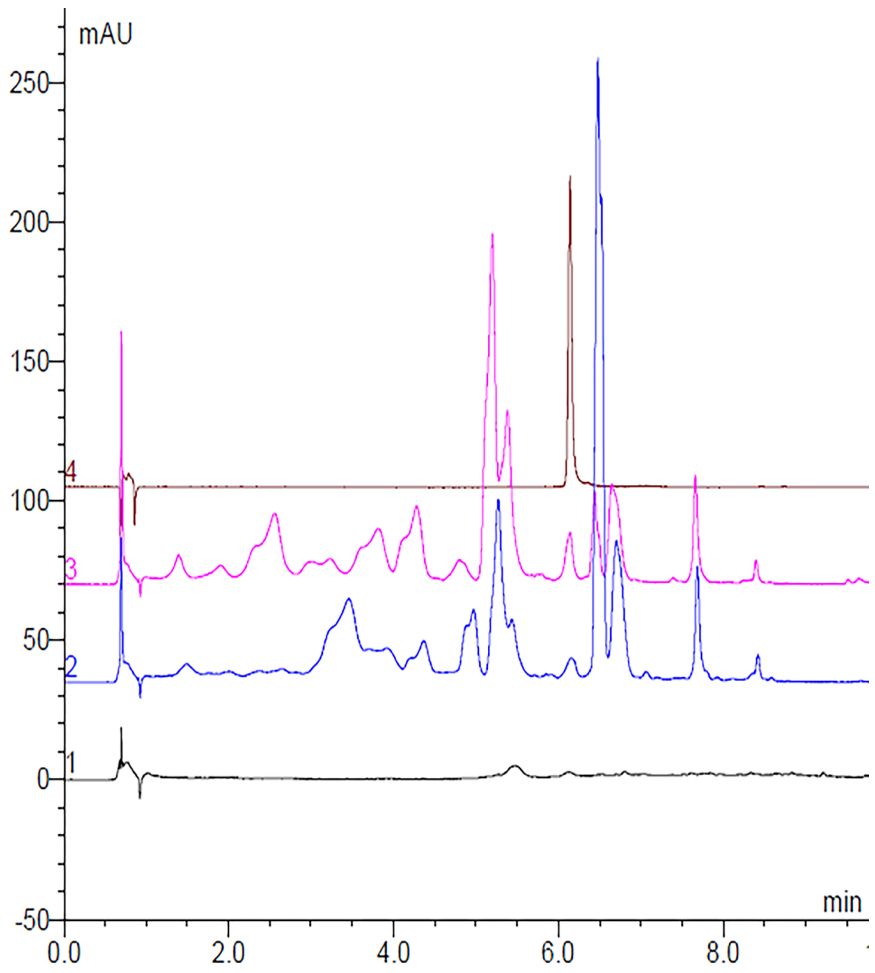

Fig. 1: Crude extracts of the Passiflora species with quantifiable amounts of vitexin. 1. P. edulis var edulis (Black). 2. P. tripartita var mollissima (Blue). 3. P. mixta (Pink). 4. Vitexin standard (Brown). Detection: $340 \mathrm{~nm}$. For details of the chromatographic method, see the section "Methodology".

Our method was able to detect vitexin in some species, even at low concentrations. P. edulis var flavicarpa, P. tarminiana, and $P$. tripartita var. tripartita presented quantities of this flavonoid below LOQ (Table 1). This result is consistent with some data from the literature reporting the quantification in species such as P. quadrangularis, P. alata, P. edulis var flavicarpa, and $P$. edulis var edulis, in which the concentration of this compound is low, unquantifiable, or undetectable (Gomes et al., 2017; Costa et al., 2016; Zucolotto et al., 2012).

Therefore, the poor presence of vitexin indicates the low viability of this flavonoid as a chemical marker in the species analyzed in this study, except for $P$. mixta, and $P$. tripartita var mollissima. On the other hand, vitexin derivatives such as isovitexin-2"-O-rhamnoside, vitexin-2"-O-xyloside and especially vitexin-2"-O-rhamnoside, found as a commercial standard, could be used as preferable analytical markers and even as potential therapeutic markers, as they are the major compounds in some Passiflora species (Costa et al., 2013) and have been related to its pharmacological activities. Some biological effects attributed to those vitexin derivatives are: antioxidant, improvement in survival and function of ADSCs (adipose-derived stem cells) in vitro, and strong inhibition of DNA synthesis in MCF-7 breast cancer cells in the case of vitexin-2"-O-rhamnoside (Wei et al., 2014; Ninfali et al., 2007). Also in relation to vitexin2"-O-xyloside, a recent study concluded that it has the ability to inhibit the proliferation of both $\mathrm{CaCo}-2$ colon cancer cells and HepG2 liver cancer cells and that the effect was magnified by the combination with avenanthramides (Scarpa et al., 2017). Other authors have confirmed the cytotoxicity in CaCo-2 tumor cell lines, and a synergistic effect when it is combined with other phytochemicals such us betalains, epigallocatechin-3-gallate and isothiocyanates (Farabegoli et al., 2017).

\section{Passiflora botanical drugs}

The Passiflora products licensed in Colombia are indicated as sedatives and adjuvants in the treatment of anxiety and sleep disorders of nervous origin. Only two species are approved to be commercialized as botanical drugs: P. tripartita var mollissima and $P$. incarnata, with flowers and leaves considered as raw material for extraction (INVIMA. Instituto Nacional de Vigilancia de Medicamentos y Alimentos, 2017). An analysis of the products most commonly found in Bogotá D.C, Colombia gave the following results: Vitexin could be detected and quantified in four (A-1, A-2, B-1 and B-2) of the six botanical drugs analyzed (Table 2, Figure 2). It is important to highlight the presence of higher amounts of vitexin in $P$. tripartita var mollissima products compared to the low levels detected in our aqueous extract of the same species. These differences in vitexin content could be related mainly to the solvent used in the extraction process, once the botanical drugs claims to be produced from a hydroalcoholic extract while ours extracts were aqueous infusion. The difference in the solubility of vitexin between ethanol and water corroborates with the observed results (Chen et al., 2017).

Products $\mathrm{C}-1$ and $\mathrm{C}-2$ containing $P$. incarnata, the species reported in most of the Pharmacopoeias and most recognized worldwide, did not contain vitexin (Figure 3 ). This indicates additional efforts to develop adequate methods for analyzing herbal products or botanical drugs that will accurately characterize the species and enable quality control of the products. 


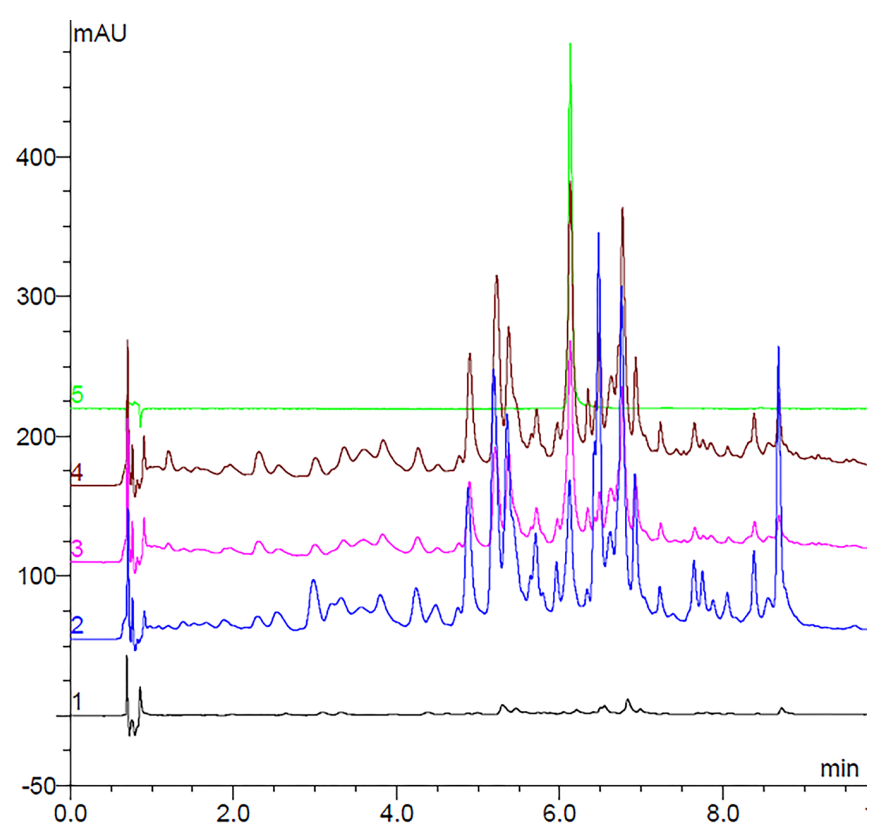

Fig. 2: Passiflora mollissima products. 1. A-2 (Black). 2. A-1 (Blue). 3. B-1 (pink). 4. B-2 (Brown). 5. Vitexin standard (green). Detection: $340 \mathrm{~nm}$. For details of the chromatographic method, see the section "Methodology".

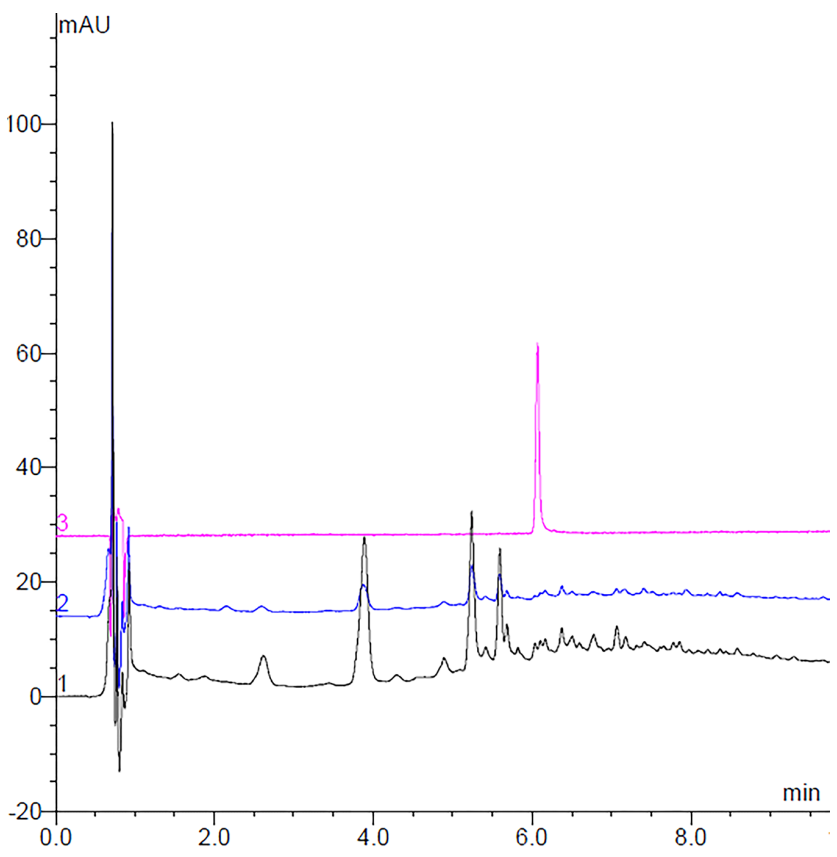

Fig. 3: Passiflora incarnata products. 1. C-1 (Black). 2. C-2 (Blue). 3. Vitexin standard (pink). Detection: $340 \mathrm{~nm}$. For details of the chromatographic method, see the section "Methodology".

\section{CONCLUSIONS}

Based on the results obtained in the validation parameters, linearity, precision, accuracy, LOD and LOQ, a reliable UHPLCDAD method was developed for the quantification of vitexin in distinct matrices from different Passiflora species. Only three of the ten evaluated species contained quantifiable amounts of this flavonoid: P. mixta, P. tripartita var mollissima, and $P$. edulis var edulis. Three species contained vitexin below the limit of quantification, and four did not contain this flavonoid, or else it was found in lower concentrations than the limit of detection. Based on these results, the use of vitexin as a chemical marker for the quality control of highly cultivated Passiflora species in Colombia is not recommended.

The method was also useful in the analysis of Passiflora products commercialized in Bogotá. It was possible to identify three products with significant quantities of vitexin, as well as one with low amounts, and two products of $P$. incarnata leaves with undetectable quantities.

\section{CONFLICT OF INTEREST}

The authors declare no conflicts of interest.

\section{ACKNOWLEDGMENTS}

The authors are grateful for the financial support provided by Fondo Nacional de Financiamiento para la Ciencia, la Tecnología y la Innovación, Francisco José de Caldas. Contract No. 0459-2013, Red Nacional para la Bioprospección de Frutas Tropicales-RIFRUTBIO.

\section{REFERENCES}

Agência Nacional de Vigilância Sanitária, Fundação Oswaldo Cruz. 2010. Farmacopeia Brasileira. Brasília, Brasil.

Ayres A, Araújo L, Soares TC, Costa GM, Reginatto FH, Ramos FA, Castellanos L, Schenkel EP, Soares VP, Zucolotto SM, Gavioli EC. Comparative central effects of the aqueous leaf extract of two populations of Passiflora edulis. Rev Bras Farmacogn, 2015; 25(5):499-505.

British Pharmacopoeia. 2009. Passion Flower. London, England. Cardozo RH, Córdoba SL, González JD, Guzman JR, Lancheros HO, Mesa LI, Pacheco RA, Pérez BA, Ramos FA, Torres ME, Zúñiga PT. 2009. Especies útiles en la Región Andina de Colombia Tomo I. Bogotá, Colombia. Ed. Jardín Botánico de Bogotá José Celestino Mutis.

Chen F, Zhang Q, Liu J, Gu H, Yang L. An efficient approach for the extraction of orientin and vitexin from Trollius chinensis flowers using ultrasonic circulating technique. Ultrason Sonochem, 2017; 37:267-278.

Costa GM, Gazola AC, Madóglio FA, Zucolotto SM, Reginatto FH, Castellanos L, Ramos FA, Duque C, Schenkel EP. Vitexin derivatives as chemical markers in the differentiation of the closely related species Passiflora alata Curtis and Passiflora quadrangularis Linn. J Liq Chromatogr Relat Technol, 2013; 36:1697-707.

Costa GM, Gazola AC, Zucolotto SM, Castellanos L, Ramos FA, Reginatto HF, Schenkel EP. Chemical profiles of traditional preparations of four South American Passiflora species by chromatographic and capillary electrophoretic techniques. Rev Bras Farmacogn, 2016; 26(4):451-8.

Dhawan K, Dhawan S, Sharma A. Passiflora: A review update. J Ethnopharmacol, 2004; 94(1):1-23.

European Pharmacopoeia. 2011. Passion Flower.

Farabegoli F, Scarpa ES, Frati A, Serafini G, Papi A, Spisni E, Antonini E, Benedetti S, Ninfali P. Betalains increase vitexin-2-O-xyloside cytotoxicity in CaCo-2 cancer cells. Food Chem, 2017; 218:356-64.

Farag MA, Otify A, Porzel A, Michel CG, Elsayed A, Wessjohann LA. 2016. Comparative metabolite profiling and fingerprinting of genus Passiflora leaves using a multiplex approach of UPLC-MS and NMR analyzed by chemometric tools. Springer.

Fischer IH, Rezende JA. Diseases of Passion Flower (Passiflora spp). Pest Technol, 2008; 2(1):1-19.

Gomes SVF, Portugal LA, dos Anjos JP, de Jesus ON, de Oliveira EJ, David JP, David JM. Accelerated solvent extraction of phenolic compounds exploiting a Box-Behnken design and quantification of five 
flavonoids by HPLC-DAD in Passiflora species. Microchem J, 2017; 132:28-35.

Hernández R, Bernal A. Lista de Especies de Passifloraceae de Colombia. Biota Colomb, 2000; 1(3):320-35.

He M, Min JW, Kong WL, He XH, Li JX, Peng BW. A review on the pharmacological effects of vitexin and isovitexin. Fitoterapia, 2016; 115:74-85.

ICH. 2005. Validation of Analytical Procedures: Text and Methodology - Q2(R1). London, England.

INVIMA. Instituto Nacional de Vigilancia de Medicamentos y Alimentos. 2017. Consulta de registros sanitarios. [ONLINE] Available at: http://farmacovigilancia.invima.gov.co:8082/Consultas/consultas/consreg encabcum.jsp. [Accessed 4 Mar 2017].

Li H, Zhou P, Yang Q, Shen Y, Deng J, Li L, Zhao D. Comparative studies on anxiolytic activities and flavonoid compositions of Passiflora edulis "edulis" and Passiflora edulis "flavicarpa". J Ethnopharmacol, 2011; 133(3):1085-90.

Ninfali P, Bacchiocca M, Antonelli A, Biagiotti E, Di Gioacchino AM, Piccoli G, Stocchi V, Brandi G. Characterization and biological activity of the main flavonoids from Swiss Chard (Beta vulgaris subspecies cycla). Phytomedicine, 2007; 14(2-3):216-21.

Ocampo J, Coppens G, Restrepo M, Jarvis A, Salazar M, Caetano C. Diversity of Colombian Passifloraceae: biogeography and an updated list for conservation. Biota Colomb, 2007; 8(1):1-45.

Ocampo J, Wyckhuys K. 2012. Tecnología para el cultivo de la Gulupa (Passiflora edulis f. edulis Sims) en Colombia. Bogotá, Colombia: Centro de Bio-Sistemas de la Universidad Jorge Tadeo Lozano, Centro Internacional de Agricultura Tropical - CIAT y Ministerio de Agricultura y Desarrollo Rural.
Patel SS, Soni H, Mishra K, Singhai AK. Recent updates on the genus Passiflora: A review. Int J Res Phytochem Pharmacol, 2011; 1(1):116.

Ramos FA, Castellanos L, López C, Palacios L, Duque C, Pacheco R, Guzmán A. An Orientin Derivative Isolated from Passiflora tripartita var. mollissima. Latin American Journal of Pharmacy, 2010; 29(1):141-3.

Real Farmacopea Española. 2002. Passiflora, Sumidad De Passiflorae herba.

Scarpa ES, Antonini E, Palma F, Mari M, Ninfali P. Antiproliferative activity of vitexin-2-O-xyloside and avenanthramides on CaCo-2 and HepG2 cancer cells occurs through apoptosis induction and reduction of pro-survival mechanisms. Eur J Nutr, 2017; 1-15.

Wei W, Ying X, Zhang W, Chen Y, Leng A, Jiang C, Liu J. Effects of vitexin-2"-O-rhamnoside and vitexin-4"-O-glucoside on growth and oxidative stress-induced cell apoptosis of human adipose-derived stem cells. J Pharm Pharmacol, 2014; 66(7):988-97.

Zucolotto SM, Fagundes C, Reginatto FH, Ramos FA, Castellanos L, Duque C, Schenkel EP. Analysis of C-glycosyl flavonoids from South American Passiflora species by HPLC-DAD and HPLC-MS. Phytochem Anal, 2012; 23(3):232-9.

How to cite this article:

Sepúlveda P, Costa GM, Aragón DM, Ramos F, Castellanos L. Analysis of vitexin in aqueous extracts and commercial products of Andean Passiflora species by UHPLC-DAD. J App Pharm Sci, 2018; 8(09): 081-086. 